\title{
PENYULUHAN HIPERTENSI MELALUI WHATSAPP GROUP SEBAGAI UPAYA PENGENDALIAN HIPERTENSI
}

\author{
Fakhriyah $^{1)}$, Noor Athiyya²), Jubaidah²), Lisa Fitriani²) \\ 1)Departemen KIA dan Kesehatan Reproduksi, Program Studi Kesehatan Masyarakat, Fakultas Kedokteran, Universitas \\ Lambung Mangkurat, Banjarmasin, Kalimantan Selatan, Indonesia \\ 2)Program Studi Kesehatan Masyarakat, Fakultas Kedokteran, Universitas Lambung Mangkurat, Banjarmasin, \\ Kalimantan Selatan, Indonesia \\ Corresponding author: Noor Athiyya \\ E-mail : noorathiyya@gmail.com
}

Diterima 09 April 2021, Disetujui 13 April 2021

\begin{abstract}
ABSTRAK
Artikel ini merupakan pengabdian masyarakat yang bertujuan untuk meningkatkan pengetahuan dan sikap masyarakat di Desa Aluh-Aluh Besar Kecamatan Aluh-Aluh Kabupaten Banjar dalam mencegah penyakit hipertensi. Berdasarkan hasil diagnosa komunitas, masih banyak didapatkan masyarakat yang terkena hipertensi. Selain itu, berdasarkan informasi yang diperoleh menunjukan masih rendahnya pengetahuan masyarakat mengenai hipertensi. Metode yang digunakan dalam penyuluhan ini adalah 1) perencanaan dan persiapan berupa perizinan, membuat whatsapp grup serta mengundang masyarakat sasaran. Selanjutnya tim menyusun kuesioner pre-post test, membuat materi dan media penyuluhan, 2) pelaksanaan dan proses berupa penyajian materi dan penutupan, 3) monitoring dan evaluasi, monitoring dari program ini adalah dengan selalu mem-booster pengetahuan dan sikap masyarakat, evaluasi dari program ini dapat dilihat dari peningkatan pengetahuan dan sikap masyrakat. Hasil penyuluhan menunjukan peningkatan pengetahuan mengenai penyakit hipertensi dari sebelum $76,9 \%$ dan setelah mendapatkan materi menjadi $100 \%$ dan terjadi peningkatan sikap dari sebelum $92,3 \%$ dan setelah mendapatkan materi menjadi $100 \%$.
\end{abstract}

Kata kunci: penyuluhan; hipertensi; whatsapp grup.

\begin{abstract}
This article is a community service that aims to improve the knowledge and attitudes of the community in Aluh-Aluh Besar Village, Aluh-Aluh District, Banjar Regency in preventing hypertension. Based on the results of community diagnosis, there are still many people affected by hypertension. It was, based on the information obtained, public knowledge about hypertension was still low. The methods used in this outreach are 1) planning and preparation in the form of licensing, creating whatsapp groups and inviting target communities. Furthermore, the team compiled a pre-post test questionnaire, made counseling materials and media, 2) implementation and process in the form of material presentation and closure, 3) monitoring and evaluation, monitoring of this program is to always increase community knowledge and attitudes, evaluation of this program can seen from the increase in knowledge and attitudes of the community. The results of counseling increased knowledge about hypertension before $76.9 \%$ and after the material became $100 \%$ and the attitude increased from before $92.3 \%$ and after getting the material to $100 \%$.
\end{abstract}

Keywords: counseling; hypertension; whatsapp group.

\section{PENDAHULUAN}

Hipertensi merupakan salah satu penyakit menular yang saat ini menjadi tantangan permasalahan kesehatan warga secara global. Badan Kesehatan Dunia (World Health Organization) memperkirakan jumlah hipertensi akan terus bertambah bersamaan dengan jumlah penduduk yang membesar, diperkirakan sekitar $29 \%$ atau sekitar 1,6 miliyar orang di seluruh dunia mengalami hipertensi pada tahun 2025 mendatang (Udjianti, 2011). Salah satu penyakit tidak menular yang menjadi permasalahan kesehatan yang sangat serius saat ini adalah hipertensi yang disebut the silent killer (Rahajeng \& Tuminah, 2009). Pengidap hipertensi tidak menampilkan indikasi apapun sepanjang 10 hingga 20 tahun (Guyton \& Hall, 2007) serta umumnya baru diketahui apabila sudah terjadi komplikasi pada organ sasaran seperti jantung, ginjal, otak serta mata sehingga akan mengurangi harapan hidup sebab kelemahan fungsi organ-organ tersebut yang berdampak kecacatan bahkan kematian (Chobanian et al., 2003). 
Hipertensi merupakan sesuatu kondisi dimana tekanan sistol serta diastol mengalami peningkatan yang melebihi batasan wajar tekanan ialah tekanan sistol diatas $140 \mathrm{mmHg}$ serta diastol diatas $90 \mathrm{mmHg}$ (Murwarni, 2011). Hipertensi ialah salah satu permasalahan kesehatan yang cukup berbahaya di seluruh dunia sebab hipertensi merupakan faktor risiko utama yang menuju kepada penyakit kardiovaskuler seperti serangan jantung, gagal jantung, stroke dan penyakit ginjal yang mana pada tahun 2016 penyakit jantung iskemik serta stroke jadi dua penyebab kematian utama di dunia (WHO, 2018).

Faktor-faktor yang mempengaruhi terbentuknya hipertensi dipecah dalam 2 kelompok besar yaitu faktor yang tidak bisa diubah seperti jenis kelamin, usia, genetik serta faktor yang bisa diubah seperti pola makan, kerutinan berolahraga serta lain-lain. Untuk terbentuknya hipertensi perlu peran faktor risiko tersebut secara bersama-sama (common underlying risk factor), dengan kata lain satu faktor risiko saja belum cukup menimbulkan munculnya hipertensi (Arif \& Hartinah, 2013). Permasalahan hipertensi di Indonesia masih merupakan tantangan besar dengan prevalensi yang lumayan besar, yaitu sebesar $34,1 \%$. Berdasarkan pada Hasil Utama Riskesdas 2018 mengatakan kecenderungan prevalensi hipertensi berdasrakan pada hasil pengukuran pada penduduk usia $\geq 18$ tahun menurut provinsi di Indonesia tahun 2018, Kalimantan Selatan mempunyai angka paling tinggi yaitu $44,1 \%$. Selain itu, berdasarkan diagnosis dokter pada penduduk usia $\geq 18$ tahun menurut provinsi di Indonesia tahun 2018, Kalimantan Selatan juga mempunyai prevalensi permasalahan hipertensi lebih tinggi dibanding prevalensi rata-rata di Indonesia (8,4\%) (Kemenkes, 2018).

Berdasarkan hasil diagnosa komunitas di Desa Aluh-Aluh Besar Kecamatan Aluh-Aluh Kabupaten Banjar bahwa masih banyak didapatkan masyarakat yang terkena penyakit hipertensi. Selain itu, berdasarkan informasi yang diperoleh terkait permasalahan masyarakat yaitu masih rendahnya pengetahuan masyarakat mengenai hipertensi. Timbulnya permasalahan kesehatan tidak cuma diakibatkan oleh kelalaian individu, tetapi bisa pula diakibatkan oleh ketidaktahuan warga sebagai akibat dari minimnya informasi yang benar mengenai sesuatu penyakit (Rahmadiana, 2012). Hasil penelitian Rogers menyatakan bahwa pengetahuan atau kognitif merupakan domain yang sangat penting untuk terbentuknya tindakan seseorang. Perilaku yang didasari oleh pengetahuan dan sikap yang positif maka perilaku tersebut akan bersifat langgeng (Notoadmodjo, 2007). Menurut Green yang diambil dari Notoatmodjo (2010) menegaskan bahwa perilaku kesehatan dapat dilaksanakan dengan baik apabila didukung oleh tiga faktor, yaitu 1). Predisposing factors seperti sikap, pengetahuan, tingkat pendidikan, umur, ekonomi, kepercayaan dan budaya, 2), Enabling factors seperti sarana prasarana, keterjangkauan fasilitas dan ketersediaan pelayanan kesehatan dan 3). Reinforcing factors seperti dukungan keluarga, guru, sebaya, petugas kesehatan, tokoh masyarakat, dan pengambil keputusan.

Pengetahuan atau kognitif merupakan domain yang sangat penting untuk terbentuknya tindakan seseorang (overt behaviour). Dari penelitian ternyata perilaku yang didasari oleh pengetahuan akan lebih langgeng daripada perilaku yang tidak didasari oleh pengetahuan (Notoadmodjo, 2007). Pengetahuan kesehatan memiliki pengaruh terhadap perilaku sebagai hasil jangka menengah (intermediate impact) dari pendidikan kesehatan. Kemudian perilaku kesehatan akan memiliki pengaruh terhadap meningkatnya indikator kesehatan masyarakat sebagai keluaran (outcome) pendidikan kesehatan (Sukmadianata, 2009). Pendapat yang dikemukaan oleh Limbong dkk (2016) bahwa faktor individu seperti pengetahuan dan sikap yang baik tentang hipertensi dapat mempengaruhi perilaku masyarakat dalam mencegah hipertensi (Limbong et al., 2018).

Kurangnya pengetahuan akan mempengaruhi pasien hipertensi untuk dapat mengatasi kekambuhan atau melakukan pencegahan agar tidak terjadi komplikasi. Sehingga pengetahuan serta sikap tentang hipertensi merupakan suatu hal yang sangat penting untuk dimiliki, agar bisa menanggulangi penyakit hipertensi itu sendiri (Wawan \& Dewi M, 2010).

Berdasarkan penelitian Muthia dkk, didapatkan bahwa terdapat perbedaan yang bermakna antara tingkat pengetahuan akhir dengan tingkat pengetahuan awal pada responden yang mendapat penyuluhan kesehatan. Penyuluhan kesehatan merupakan suatu kegiatan yang dapat mempengaruhi perubahan perilaku responden, salah satunya perubahan pengetahuan. Dengan diberikannya penyuluhan maka responden mendapat pembelajaran yang menghasilkan suatu perubahan dari yang semula belum mengetahui menjadi mengetahui dan yang dahulu belum memahami menjadi memahami (Muthia et al., 2016).

Penyuluhan kesehatan merupakan kegiatan pendidikan kesehatan, yang dilakukan dengan menyebarkan pesan, menanamkan 
keyakinan sehingga masyarakat tidak saja sadar, tahu dan mengerti, tetapi juga mau dan dapat melakukan anjuran yang berhubungan dengan kesehatan (Ali, 2000). Penyuluhan kesehatan adalah penambahan pengetahuan dan kemampuan seseorang melalui teknik praktik belajar atau instruksi dengan tujuan mengubah atau mempengaruhi perilaku manusia baik secara individu, kelompok maupun perawat dan pasien untuk meningkatkan kesadaran akan nilai kesehatan sehingga dengan sadar mau mengubah perilakunya menjadi perilaku hidup sehat (Simamora \& Saragih, 2019).

Penyuluhan kesehatan merupakan suatu cara merubah diri seseorang melalui informasai yang didapatkan untuk melakukan sesuai dengan yang diinginkan oleh yang memberikan penyuluhan (Budioro, 2012). Pengetahuan individu mempengaruhi kesadaran terhadap perilaku pencegahan hipertensi, dengan kata lain makin tinggi pengetahuan individu mengenai penyebab hipertensi, faktor pemicu, tanda gejala, dan tekanan darah normal dan tidak normal maka individu akan cenderung menghindari hal-hal yang dapat memicu terjadinya hipertensi, seperti perilaku merokok, minum kopi, dan obesitas (Sinuraya et al., 2017).

Maka dari itu, untuk menyelesaikan permasalahan yang dihadapi masyarakat, diperlukan penyuluhan untuk meningkatkan pengetahuan dan sikap masyarakat di Desa Aluh-Aluh Besar Kecamatan Aluh-Aluh Kabupaten Banjar dalam mencegah penyakit hipertensi. Pengetahuan merupakan faktor yang penting untuk terbentuknya tindakan seseorang. Melalui penyuluhan diharapkan perilaku kesehatan atau sikap masyarakat juga berubah untuk mendukung penurunan tekanan darah pada penderita hipertensi. Di sisi lain pendidikan kesehatan juga sebagai tindakan pencegahan terhadap seseorang yang memiliki risiko dan potensi terjangkit penyakit hipertensi.

\section{METODE}

Metode pelaksanaan yang digunakan adalah dengan memberikan penyuluhan kepada masyarakat. Mengingat himbauan dari pemerintah untuk tidak melakukan kegiatan yang melibatkan banyak orang, maka kegiatan ini dilakukan melalui bantuan media online yaitu WhatsApp Group (WAG). Pada pelaksanaan kegiatan pengabdian masyarakat tim terdiri dari tiga orang mahasiswa dan satu orang dosen. Jumlah masyarakat yang ikut serta dalam kegiatan sebanyak 13 orang. Kegiatan secara resmi dibuka pada tanggal 17 November 2020 dan ditutup pada tanggal 24 November 2020. Adapun langkah yang telah ditempuh dalam kegiatan program pengabdian masyarakat ini mencakup beberapa tahap berikut ini.

\section{Tahap Perencanaan dan Persiapan}

Tahap persiapan merupakan tahap awal sebelum pelaksanaan program pengabdian masyarakat ini. Dalam tahap ini ada beberapa hal yang dilakukan, yakni koordinasi internal, dilakukan oleh tim untuk merencanakan pelaksanaan secara konseptual, operasional, serta job description masingmasing anggota, melakukan perizinan, membuat whatsapp grup serta mengundang masyarakat sasaran. Selanjutnya tim menyusun kuesioner pre-test dan post-test, materi, dan media yang digunakan untuk kegiatan penyuluhan.

\section{Tahap Pelaksanaan dan Proses}

Tahap ini merupakan tahap pelaksanaan kegiatan penyuluhan kepada masyarakat Desa Aluh-Aluh Besar. Pelaksanaan dan proses ini mencakup beberapa hal berikut.

a. Penyajian Materi

Penyuluhan dilakukan melalui Whatsapp Group dengan menggunakan media berupa poster, slide powerpoint, leaflet, dan juga video singkat yang berisi mengenai penjelasan penyakit hipertensi, gejala, penyebab, faktor risiko, cara menghindari hipertensi, pentingnya pemeriksaan tekanan darah secara rutin. Sebelum diberikan materi, diberikan terlebih dahulu soal pre-test kepada masyarakat untuk mengetahui seberapa besar pengetahuan masyarakat tentang materi yang akan disampaikan oleh tim.

Kegiatan tanya jawab dilakukan setelah penyajian materi. Para peserta dapat langsung berdiskusi dengan para pemateri secara langsung dan sharing pengalaman terkait dengan masalah yang tengah dibahas dalam materi bersangkutan. Setelah kegiatan diskusi selesai dilakukan, kemudian dibagikan soal post-test terkait materi yang telah disampaikan oleh tim.

b. Penutupan

Setelah semua kegiatan yang telah direncanakan terlaksana, ketua tim Pengabdian Masyarakat menutup program dan memberikan pesan kepada segenap peserta penyuluhan untuk menerapkan apa yang telah didapatkan untuk dalam hal pencegahan dan pengendalian hipertensi.

\section{Tahap Monitoring dan Evaluasi}

a. Monitoring dari program ini adalah dengan selalu mem-booster pengetahuan masyarakat pada saat penyuluhan dan memberikan kuesioner 
untuk mengetahui sejauh mana keefektifitasan kegiatan penyuluhan yang sudah terjalankan, serta apakah ada kendala atau hambatan selama mengikuti program ini.

b. Penilaian keberhasilan kegiatan ini dapat dilihat dari peningkatan pengetahuan seperti peningkatan pengetahuan masyarakat sasaran untuk menangani permasalahan penyakit Hipertensi sebagai bentuk evaluasi dari kegiatan penyuluhan ini. Hasil perhitungan keberhasilan program ini ditinjau dari pengisian kuesioner. Pemberian kuesioner dilaksanakan dua kali yaitu pada saat sebelum penyuluhan (pre-test) dan sesudah penyuluhan (post-test). Tujuan dilaksanakannya evaluasi ini yaitu untuk menentukan keberhasilan kegiatan penyuluhan. Selain itu, evaluasi juga digunakan untuk mengetahui apakah tujuan yang telah ditentukan dapat dicapai atau tidak, apakah pelaksanaan kegiatan penyuluhan sesuai dengan rencana, serta dampak apa yang terjadi setelah kegiatan penyuluhan dilaksanakan.

\section{HASIL DAN PEMBAHASAN}

Pelaksanaan kegiatan pengabdian ini dilakukan secara daring melalui grup whatsapp. Whatsapp dipilih sebagai media dalam penyuluhan ini karena whatsapp merupakan media sosial yang digemari masyarakat saat ini dan memungkinkan pengguna dapat bertukar pesan tanpa harus membayar SMS. Selain fitur dasar berkirim pesan, pengguna whatsapp dapat membuat grup, saling berkirim gambar, pesan video, dan audio dalam jumlah tidak terbatas. Penggunaan whatsaap lebih mudah dibandingkan media lain seperti zoom ataupun google meet yang masih awam digunakan masyarakat desa dan memerlukan kuota internet yang lebih besar dan jaringan yang lebih kuat. Penelitian Utami et al (2020) menyebutkan bahwa media sosial whatsapp efektif dalam mempengaruhi orang baik secara individu, kelompok bahkan dalam jumlah yang banyak (massal) karena media sosial ini didesain untuk memudahkan interaksi sosial yang bersifat interaktif. Hasil penelitiannya menunjukkan bahwa media whatsapp dalam pendidikan kesehatan dapat meningkatkan sikap responden (Utami et al., 2020)

Peserta kegiatan adalah warga Desa Aluh-Aluh Besar RT. 07 Kecamatan Aluh-Aluh sebanyak 13 orang. Kegiatan di mulai dengan menyiapkan perizinan yang dibantu oleh pihak UP-PBL, dan mencari beberapa kontak warga yang bersedia menjadi partisipan dalam kegiatan intervensi. Pada 27 Oktober 2020 - 6 November 2020 mengundang beberapa warga yang bersedia menjadi partisipan. Pada tanggal 6 November 2020 masing-masing anggota telah melakukan perkenalan dan melakukan sosialisasi kegiatan intervensi kepada para warga. Berikut adalah karakteristik warga yang menjadi responden:

\begin{tabular}{|c|c|c|c|}
\hline No & Karakteristik & Jumlah & $\begin{array}{c}\text { Persentase } \\
(\%)\end{array}$ \\
\hline & Jenis Kelamin & & \\
\hline 1. & Laki-Laki & 1 & 7,7 \\
\hline 2. & $\begin{array}{l}\text { Perempuan } \\
\text { Umur }\end{array}$ & 12 & 92,3 \\
\hline 1. & $<30$ tahun & 9 & 69,2 \\
\hline 2. & 30-40 tahun & 3 & 23,1 \\
\hline 3. & $\begin{array}{l}>40 \text { tahun } \\
\text { Tingkat } \\
\text { Pendidikan }\end{array}$ & 1 & 7,7 \\
\hline 1. & SD & 6 & 46,2 \\
\hline 2. & SMP & 4 & 30,8 \\
\hline 3. & SMA & 3 & 23,1 \\
\hline 4. & $\begin{array}{l}\text { Perguruan } \\
\text { Tinggi/S1 } \\
\text { Pekerjaan }\end{array}$ & 0 & 0 \\
\hline 1. & Swasta & 2 & 15,4 \\
\hline 2. & Pelajar & 3 & 23,1 \\
\hline 3. & $\begin{array}{ll}\text { lbu } & \text { Rumah } \\
\text { Tangga } & \end{array}$ & 8 & 61,5 \\
\hline & Total & 13 orang & 100 \\
\hline
\end{tabular}

Tahap pertama adalah pemberian soal pre test kepada peserta kegiatan melalui google form. Soal pre test ini terdiri dari 16 soal mengenai hipertensi. Pemberian pre test ini bertujuan untuk mengetahui pengetahuan dan sikap peserta kegiatan sebelum diberikan intervensi.

Hasil pre test didapatkan bahwa pengetahuan masyarakat mengenai hipertensi dalam kategori baik sebanyak 10 orang (76.9\%) dan dalam kategori cukup sebanyak 3 orang $(23.1 \%)$. Sedangkan sikap masyarakat mengenai hipertensi dalam kategori positif sebanyak 12 orang (92,3\%). Sedangkan dalam kategori negatif sebanyak 1 orang $(7,7 \%)$.

Sejalan dengan pengabdian masyarakat sebelumnya oleh Septiana dan Ach. Faruk (2020), sebelum sosialisasi dimulai, peserta diberi kuisioner (pre-test) untuk mengetahui sejauh mana peserta tersebut memahami tentang hal-hal yang berkaitan dengan hipertensi. Diperoleh hasil, nilai pretest rata-rata peserta sebelum dilakukan sosialisasi adalah 73,85. Hal ini berarti sebagian besar peserta sedikit banyak telah memahami hal-hal yang berkaitan dengan hipertensi (Kurniasari \& Alrosyidi, 2020). 


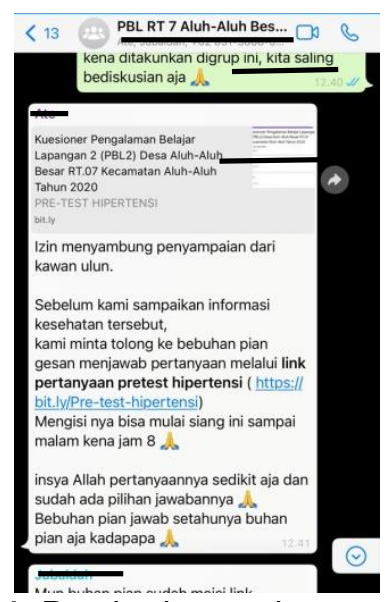

Gambar 1. Pemberian soal pre test kepada peserta

Tahap kedua yakni melakukan penyuluhan secara daring kepada masyarakat. Penyuluhan hipertensi kepada masyarakat dilakukan dengan menggunakan media intervensi berupa power point, poster, leaflet, booklet, pesan teks dan voice note whatsapp, serta video. Materi yang diberikan meliputi pengertian, penyebab, faktor risiko, cara menghindari hipertensi, serta pentingnya pemeriksaan tekanan darah. Media Power point, poster, leaflet, dan booklet dibuat dengan point-point disertai dengan gambar dan warna yang menarik. Dengan media yang menarik tersebut diharapkan masyarakat memiliki ketertarikan lebih untuk membaca informasi yang disampaikan di dalamnya. Selain itu, penjelasan yang lebih rinci disampaikan melalui pesan teks dan voice note whatsapp.

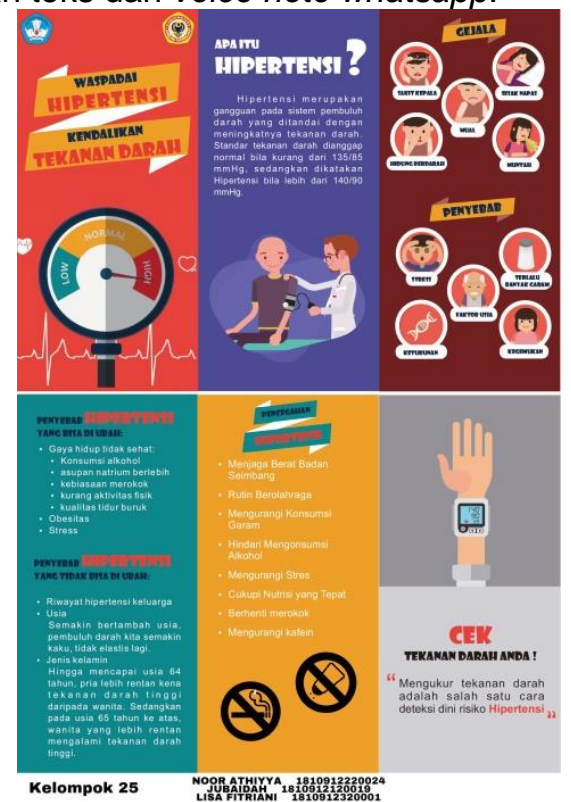

Gambar 2. Salah satu media penyuluhan berupa leaflet

Leaflet sendiri merupakan lembaran yang berisikan tentang informasi khusus. Pada isi leaflet tersedia berbagai informasi yang dibutuhkan dan didukung oleh gambar dengan tujuan pembaca dapat memahami langsung isi dari leaflet. Leaflet merupakan salah satu media yang efektif dalam mempengaruhi perilaku seseorang (Susanti et al., 2017). Sedangkan poster sendiri merupakan media yang berisikan gambar dan sedikit kata-kata. Kata-kata dalam poster harus jelas artinya, tepat pesannya, dan dapat dengan mudah dibaca (Prasanti dan Ikhsan, 2018).

Media lainnya yaitu booklet, merupakan berbentuk buku kecil. Booklet biasanya digunakan untuk topik dimana terdapat minat yang cukup tinggi terhadap suatu kelompok sasaran. Ciri lain dari booklet yaitu buku berukuran kecil dan tipis, berisi informasi yang dilengkapi dengan gambar, dilengkapi penjelasan yang ringkas dan sistematis, berisi informasi pokok tentang hal yang dipelajari sehingga mudah dipahami, ekonomis dalam arti waktu dalam memperoleh informasi, seseorang mendapat informasi dengan caranya sendiri (Prasanti dan Ikhsan, 2018). Penelitian oleh Wijayanti dan Mulyadi (2018) menunjukkan bahwa ada pengaruh pendidikan kesehatan menggunakan booklet terhadap pemahaman pasien hipertensi di Puskesmas Kecamatan Pasar Minggu Tahun 2016 (Wijayanti \& Mulyadi, 2019).

Pengetahuan merupakan faktor yang penting untuk terbentuknya tindakan seseorang. Melalui penyuluhan diharapkan perilaku kesehatan warga juga berubah untuk mendukung penurunan tekanan darah pada penderita hipertensi. Di sisi lain pendidikan kesehatan juga sebagai tindakan pencegahan terhadap seseorang yang memiliki risiko dan potensi terjangkit penyakit hipertensi (Rohmawati \& Prawoto, 2020)

Penyuluhan merupakan suatu proses pembelajaran kepada masyarakat guna mencapai tujuan yang diharapkan. Penyuluhan merupakan usaha untuk mengubah pengetahuan, sikap, kebiasaan dan keterampilan dengan membantu, mempengaruhi dan memotivasi masyarakat sehingga dapat meningkatkan taraf hidupnya. Penyuluhan merupakan pendidikan yang diselenggarakan secara sistematis ditujukan pada masyarakat agar mau, mampu dan berswadaya dalam memperbaiki atau meningkatkan kesejahteraan keluarganya dan masyarakat luas (Avessina et al., 2018). 


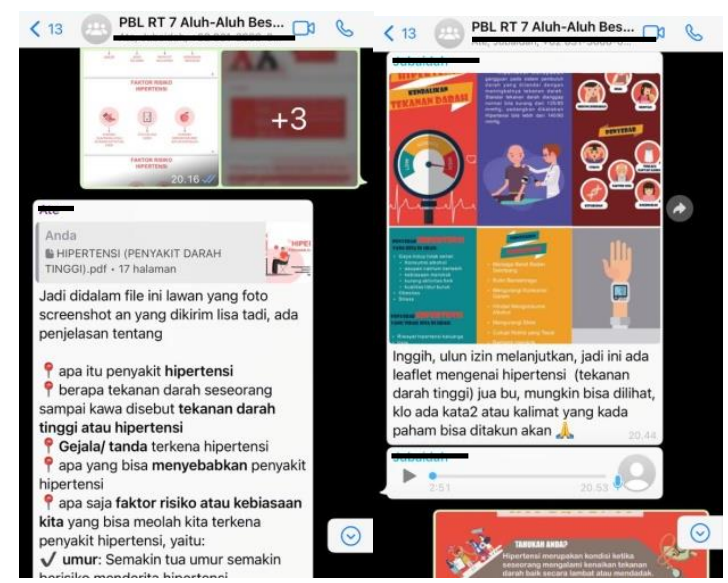

Gambar 3. Kegiatan penyuluhan secara daring kepada peserta

Selanjutnya, tahap ketiga yakni pemberian soal post test kepada peserta kegiatan melalui google form. Tahapan ini untuk mengetahui output, efek ataupun dampak program apakah sudah sesuai dengan target yang ditetapkan sebelumnya. Output dari kegiatan intervensi penyuluhan yang dilakukan adalah meningkatnya pengetahuan masyarakat sasaran untuk menangani permasalahan penyakit Hipertensi. Untuk mengetahui output dari kegiatan intervensi penyuluhan ini adalah dengan membandingkan hasil dari nilai pre test (sebelum materi penyuluhan disampaikan) serta nilai post test (setelah pemberian materi penyuluhan).

Menurut Mahmudi (2005) yang dikutip oleh Wijayanti (2018), pelaksanaan pendidikan kesehatan merupakan hubungan antara output dengan tujuan, semakin besar kontribusi output terhadap pencapaian tujuan maka semakin efektif organisasi, program, atau kegiatan. Sehubungan dengan hal tersebut, maka pelaksanaan pendidikan kesehatan mengacu pada hasil guna dari pendidikan kesehatan yang menyatakan sejauh mana tujuan telah dicapai, serta ukuran berhasil tidaknya pelaksanaan pendidikan kesehatan mencapai tujuan dan targetnya (Wijayanti dan Mulyadi, 2019).

Hasil dari post test didapatkan bahwa pengetahuan masyarakat mengenai hipertensi dalam kategori baik sebanyak 13 orang (100\%) dan sikap masyarakat mengenai hipertensi dalam kategori sikap positif sebanyak 13 orang (100\%). Hal ini menunjukkan bahwa terjadi peningkatan pengetahuan dan sikap masyarakat sebelum dan sesudah diberikan intervensi berupa penyuluhan.

Sejalan dengan penelitian Nelwan (2019), bahwa terjadi peningkatan pengetahuan masyarakat sebelum (pre) dan sesudah (post) diberikan promosi kesehatan berupa penyuluhan mengenai hipertensi. Hasil penelitiannya menunjukkan bahwa terdapat peningkatan pengetahuan sebesar 1,44 poin. Hal ini berarti pemberian promosi kesehatan bisa meningkatkan pengetahuan (Nelwan \& Sumampouw, 2019).

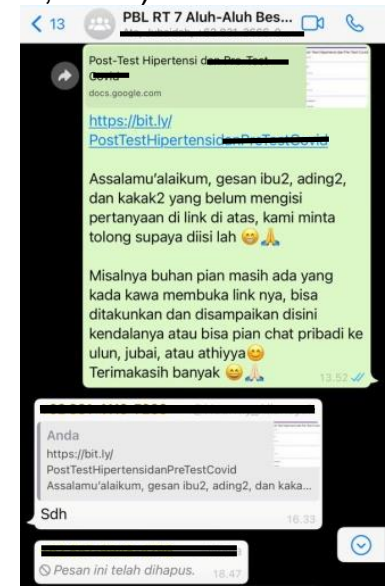

Gambar 4. Pemberian soal post test kepada peserta

\section{SIMPULAN DAN SARAN}

Kegiatan penyuluhan mengenai penyakit hipertensi kepada 13 orang responden RT.07 Desa Aluh-Aluh Besar didapatkan hasil pada penyuluhan mengenai penyakit hipertensi, terjadi peningkatan pengetahuan mengenai penyakit hipertensi dengan kategori baik, dari sebelum $76,9 \%$ dan setelah mendapatkan materi menjadi $100 \%$ dan terjadi peningkatan sikap dengan kategori positif, dari sebelum 92,3\% dan setelah mendapatkan materi menjadi $100 \%$.

Diharapakan tenaga kesehatan dan pihak puskesmas dapat membantu masyarakat dengan memberikan penyuluhan tentang penyakit hipertensi. Selain itu, diharapkan masyarakat Desa Aluh-Aluh Besar RT. 07 untuk bisa memperhatikan kesehatannya terkhusus permasalahan penyakit hipertensi dimulai dengan menghindari faktor risiko penyakit hipertensi seperti kebiasaan merokok, stres, kemudian melakukan pemeriksaan tekanan darah rutin ke pelayanan kesehatan terdekat, menjaga pola makan dan melakukan pencegahan salah satunya dengan aktivitas fisik.

$\begin{array}{ccc}\text { Diharapkan } & \text { mahasiswa dalam } \\ \text { penyampaian } & \text { pesan/informasi } & \text { perlu }\end{array}$ meningkatkan penggunaan metode yang komunikatif dan partisipatif. Selain itu, proses penyampaian pesan/informasi dalam kegiatan penyuluhan dengan penggunaan media harus jelas, menarik dan interaktif, sehingga dapat meningkatkan kualitas pesan yang disampaikan.

\section{UCAPAN TERIMAKASIH}

Kami ucapkan terima kasih kepada Universitas Lambung Mangkurat dan 
masyarakat Desa Aluh-Aluh Besar Kecamatan Aluh-Aluh Kabupaten Banjar, karena telah membantu, terlibat dan berperan dalam terselenggaranya pengabdian kepada masyarakat ini.

\section{DAFTAR RUJUKAN}

Ali, Z. (2000). Dasar-dasar keperawatan Professional. Jakarta: Widya Medika.

Arif, D., \& Hartinah, D. (2013). Faktor-Faktor yang Berhubungan dengan Kejadian Hipertensi Pada Lansia di Pusling Desa Klumpit UPT Puskesmas Gribig Kabupaten Kudus. JIKK 4(2): 18-34.

Avessina, M. J., Kustari, S. A., Anisa, Z. (2018). Pemberdayaan Masyarakat Melalui Komunikasi Penyuluhan. Jurnal Pengabdian Pada Masyarakat 2(3): 273-281.

Budioro. (2012). Pengantar Pendidikan (Penyuluhan) Kesehatan Masyarakat, Edisi Revisi. Semarang: UNDIP.

Chobanian, A. V. et al. (2003). The Seventh Report of the Joint National Committee on Prevention, Detection, Evaluation, and Treatment of High Blood Pressure: The JNC 7 Report. Journal of the American Medical Association 289(19): 2560-2572.

Guyton, A. C., \& Hall, J. E. (2007). Buku Ajar Fisiologi Kedokteran (Terjemahan). Edisi 11. Penerjemah: Irawati, Ramadani D, Indriyani F. Jakarta: Penerbit Buku Kedokteran EGC.

Kemenkes RI. (2018). Riset Kesehatan Dasar RI. Jakarta: Kemenkes RI.

Kurniasari, S., \& Alrosyidi, A. F. (2020). Penyuluhan Hipertensi dan Pemeriksaan Tekanan Darah Pada Kelompok Ibu-lbu. Jurnal Pengabdian dan Pemberdayaan Masyarakat 1(2): 74-78.

Limbong, V. A., Rumayar, A., Kandou, G. D. (2018). Hubungan Pengetahuan dan Sikap dengan Kejadian Hipertensi di Wilayah Kerja Puskesmas Tateli Kabupaten Minahasa. Jurnal Kesmas 7(4): $1-5$.

Murwarni, A. (2011). Perawatan Pasien Penyakit Dalam. Yogyakarta: Gosyen Publishing.

Muthia, F., Fitriangga, A., Yanti, S. N. (2016). Perbedaan Efektifitas Penyuluhan Kesehatan Menggunakan Metode Ceramah dan Media Audiovisual (Film) Terhadap Pengetahuan Santri Madrasah Aliyah Pesantren Khulafaur Rasyidin tentang TB paru tahun 2015. Jurnal Cerebellum 2(4): 646-656.

Nelwan, J. E., \& Sumampouw, O. (2019).
Volume 4, Nomor 2., April 2021. p-ISSN : 2614-5251

e-ISSN : 2614-526X

Pengaruh Penyuluhan Kesehatan Terhadap Perubahan Pengetahuan Masyarakat Tentang Hipertensi di Kota Manado. Jurnal PHWB 1(2): 1-7.

Notoadmodjo, S. (2007). Pendidikan dan Perilaku Kesehatan. Jakarta: Rineka Cipta.

Notoadmodjo, S. (2007). Promosi Kesehatan, Teori dan Aplikasi. Jakarta: Rineka Cipta.

Prasanti D, Ikhsan F. 2018. Pemanfaatan media komunikasi dalam penyebaran informasi kesehatan kepada masyarakat. REFORMASI 8(1): 8-14.

Rahajeng, E., \& Tuminah, S. (2009). Prevalensi Hipertensi dan Determinannya di Indonesia. Majalah Kedokteran Indonesia 59(12): 580-587.

Rahmadiana, M. (2012). Komunikasi Kesehatan: Sebuah Tinjauan. Jurnal Psikogenesis 1(1): 88-94.

Rohmawati, D. L., \& Prawoto, E. (2020). Pemberdayaan Masyarakat Peduli Hipertensi Sebagai Upaya Penurunan Tekanan Darah Melalui Terapi Komplementer. Journal of Community Health Development 1(1): 62-67.

Simamora, R. H., \& Saragih, E. (2019). Penyuluhan Kesehatan Masyarakat: Penatalaksanaan Perawatan Penderita Asam Urat Menggunakan Media Audiovisual. JPPM (Jurnal Pendidikan dan Pemberdayaan Masyarakat) 6(1): 24-31.

Sinuraya, R. K. et al. (2017). Pengukuran Tingkat Pengetahuan Tentang Hipertensi Pada Pasien Hipertensi di Kota Bandung. Jurnal Farmasi Klinik Indonesia 6(4): 290-297.

Sukmadianata. (2009). Landasan Psikologi Proses Pendidikan. Bandung: PT. Remaja Pusdakarya.

Susanti, N. et al. (2017). Efektifitas Leaflet Terhadap Pengetahuan dan Mengatur Pola Makan Lansia Penderita Hipertensi di Puskesmas Serasan Kabupaten Natuna. Photon: Jurnal Sain dan Kesehatan 7(2): 33-38.

Udjianti, W. J. (2011). Keperawatan Kardiovaskuler. Jakarta: Salemba Medika.

Utami, R. B., et al. (2020). Efektifitas Penggunaan Media Melalui Whatsapp dan Booklet Terhadap Sikap Ayah ASI di Wilayah Kerja Puskesmas Tuan Tuan Kecamatan Benua Kayong Kabupaten Ketapang. Jurnal Kebidanan Khatulistiwa 6(2): 1-8.

Wawan, A., \& Dewi, M. (2010). Pengetahuan, Sikap, dan Perilaku Manusia. Jakarta: 
Nuha Medika.

WHO. (2018). Global Health Estimates 2016: Deaths by Cause, Age, Sex, by Country and by Region, 2000-2016. Geneva: World Health Organization.

Wijayanti \& Mulyadi, B. (2019). Pendidikan Kesehatan Menggunakan Booklet Terhadap Pemahaman Pasien Hipertensi di Puskesmas. Jurnal IImiah IImu Keperawatan Indonesia 8(1): 372739. 